\title{
DRG data for better decision-making in Croatia: planning for a greater use of same-day surgical admissions
}

\author{
Karolina Kalanj, Karl Karol \\ From Patient Classification Systems International 2014 - Patient information for better choice \\ Doha, Qatar. 20-23 October 2013
}

\section{Background}

In 2006, Croatia implemented AR-DRGs with the aim of increasing hospital output transparency, incentivizing efficient resource use, and measuring hospital performance and quality. Despite the intentions of this initiative, up until very recently, the hospital payment system continued to be based on historical budgets, although hospitals have been reporting inpatient activity using the DRG classifications. Only now is transition to a DRGbased payment system being planned.

In 2013-2014, a Hospital Master Planning Project was undertaken to rationalize the hospital service delivery network and to improve efficiency. The Project also sought to create incentives to encourage the greater use of same-day inpatient services and improve the organization of the delivery of rehabilitation and palliative care services. The Project reported that the Croatian Health Insurance Fund (HZZO) does not have a strategy to encourage the utilization of same-day admissions. These services are primarily counted as part of the total DRG output for all admitted cases. Croatia uses AR-DRG version 5.2, which provides for 20 designated same-day DRGs.

In the case of same-day surgical cases, the HZZO pays hospitals through two parallel systems. The first is through DRGs, where there are only 2 are same-day surgical groups (C15B and C16B); the second is through the outpatient system, which has 17 same-day surgical case categories that, in terms of clinical activity, are replicated in the DRG system. The use of both systems and their uncoordinated pricing creates a situation in which hospitals do not have financial incentives to increase the use of same-day surgical procedures.

Recognizing that the increased use of same-day admissions would improve hospital efficiency, the Master Planning Project recommended that these admissions should be increased by $20 \%$ to $40 \%$ over a 3 -year period. It appears, however, that these recommendations were made in the absence of a detailed analysis of the types of same-day procedures currently provided by hospitals. The Project did not recommend how hospital could increase their volume of same-day inpatient services, describe individual hospitals' capacity to do so, or analyze hospital waiting lists.

\section{Materials and methods}

We analyzed DRG activity data for Croatian Clinical Centres, because these institutions have both the greatest volume and the greatest potential to increase the number of same-day inpatient procedures, given appropriate incentives.

The analysis looked at HZZO DRG data from all of the Centres' surgical cases in which patients were discharged either same-day or after one-night stay (oneday cases). The methodology was selected because it was probable that many of the one-day cases could have been treated on a same-day basis, given the appropriate financial incentives.

The data analysis also looked specifically at cataract surgery, which is included in both the DRG payment model (C15B) and the outpatient payment model. The analysis compared the incidence of same-day cataract surgery cases in other hospital systems.

* Correspondence: karolina.kalanj@zg.t-com.hr Karol Consulting, Zagreb, 10,000, Croatia 
Table 1. DRG patient data distribution, 2012

\begin{tabular}{|c|c|c|c|c|c|}
\hline $\begin{array}{l}\text { Clinical } \\
\text { Centre }\end{array}$ & $\begin{array}{c}\text { Number of } \\
\text { admissions (NA) }\end{array}$ & $\begin{array}{l}\text { Number of surgical } \\
\text { admissions (SA) }\end{array}$ & $\begin{array}{l}\text { Same-day and one-day surgical } \\
\text { admissions (SOD) }\end{array}$ & $\begin{array}{l}\mathrm{SOD} / \\
\mathrm{SA} \%\end{array}$ & $\begin{array}{l}\text { Same-day cataract surgery cases as \% of all } \\
\text { cataract surgical cases }\end{array}$ \\
\hline Zagreb & 72,733 & 28,956 & 9,446 & $33 \%$ & $11 \%$ \\
\hline Split & 51,030 & 19,249 & 5,465 & $28 \%$ & $21 \%$ \\
\hline Osijek & 40,622 & 15,187 & 4,944 & $33 \%$ & $0.3 \%$ \\
\hline Rijeka & 40,439 & 17,606 & 5,185 & $29 \%$ & $25 \%$ \\
\hline $\begin{array}{l}\text { Sisters of } \\
\text { Mercy }\end{array}$ & 56,603 & 25,745 & 5,689 & $22 \%$ & $9 \%$ \\
\hline $\begin{array}{l}\text { Total/ } \\
\text { Average }\end{array}$ & 261,427 & 106,743 & 30,729 & $29 \%$ & $13 \%$ \\
\hline
\end{tabular}

Source: 2012 DRG data from Croatian Health Insurance Fund (HZZO)

\section{Results}

According to HZZO's DRG data, five Croatian Clinical Centres reported that between 22\% and 33\% (an average of $29 \%$ ) of all surgical admissions were either same-day or one-day surgical cases (see Table 1). This is consistent with research from Italy reporting that one-day and same-day cases account for around $20 \%$ and $25 \%$ of all surgical cases [1].

The number of cataract surgery cases performed by the Centres was comparatively low, compared to levels in other European Union (EU) countries. On average, $13 \%$ of the Croatian Clinical Centres' cataract cases were undertaken on a same-day basis (see Table 1), compared to a 15-country EU average of 71\% [2]. Other research indicates that low rates of same-day surgery for cataracts and other interventions result from disadvantageous payment models that do not provide incentives for same-day admissions [3].

\section{Conclusions}

The Croatian hospital contracting model that is currently in use does not encourage the use of same-day admissions, and the payment system does not provide hospitals with incentives to discharge patients the same day. With the right incentives, however, we conclude that the Croatian Clinical Centres can significantly increase same-day admissions, which would improve their efficiency.

Croatian decision-makers should make appropriate use of the available DRG data to develop strategies to increase the use of same-day procedures, where clinically appropriate.

We also believe that, by not utilizing the available DRG data, it is likely that the Hospital Master Planning Project substantially underestimated the opportunity to increase same-day surgical cases.

Published: 15 June 2015

\section{References}

1. Porcellini A, Ventura P, Federico L: Ordinary hospitalisation, day surgery and one-day surgery: appropriateness and economic considerations in the DRG era. Chir Ital 2007, 59(4):461-6.

2. Lafortune $G$, Balestat $G$, Durand $A$ : Comparing activities and performance of the hospital sector in Europe: how many surgical procedures performed as inpatient and day cases? Paris: Organisation for Economic Co-operation and Development (OECD) Health Division, Directorate for Employment, Labour and Social Affairs; 2012

3. Castoro C, Bertinato L, Baccaglini U, Drace CA, McKee M: Day surgery: making it happen - Policy Brief. Copenhagen: World Health Organization European Region and the European Observatory on Health Systems and Policies; 2007.

doi:10.1186/1472-6963-15-S2-A4

Cite this article as: Kalanj and Karol: DRG data for better decisionmaking in Croatia: planning for a greater use of same-day surgical admissions. BMC Health Services Research 2015 15(Suppl 2):A4.

\section{Submit your next manuscript to BioMed Central} and take full advantage of:

- Convenient online submission

- Thorough peer review

- No space constraints or color figure charges

- Immediate publication on acceptance

- Inclusion in PubMed, CAS, Scopus and Google Scholar

- Research which is freely available for redistribution

Submit your manuscript at www.biomedcentral.com/submit 